\title{
MENINGKATKANKEMAMPUAN MOTORIK KASARANAK MELALUI GERAK DAN LAGUUSIA 5 - 6 TAHUN DI TKPGRI MARANGKAYU TAHUN AJARAN 2017/2018
}

\author{
Rikha Kusmalia \\ PG PAUD, FKIP, Universitas Widya Gama Mahakam Samarinda \\ ( almabungsu92@gmail.com) \\ Hanita \\ PG PAUD, FKIP, Universitas Widya Gama Mahakam Samarinda \\ ( nitahanita87@gmail.com )
}

\begin{abstract}
This study aims to improve 5-6 year old students' gross motor skill through song and movement in PGRI Kindergarten Marangkayu, as well as, to revel and explain the obstacles and supporting factors.The main theory referred in this study is based on curriculum 2013 about early childhood education, regarding to the characteristics of teaching young learnes ; 1) develop learner's development optimally which covers the aspect of religious and moral value, physical-motor skill, attitude, knowledge, and skill; 2) apply thematic learning and scientific approach in stimulating education; 3) use authentic assessment in observing learner's development, and 4) empower parents' rolein learning process.The researcher conducted a classroom action research which involved students of PGRI Kinfergarten as the research subjects. The learning activity carried out by the researcher was by using movement and songs during two cycles, wherein each cycle consists of three mettings. The result of analysis show that the activity of song snd movement managed to improve students' gross motor skill, which can be seen in the recapitulation of percentage of students' gross motor skill assessment. At cycle 1, the average score was $53,7 \%$, meanwhile, in cycle 2 , becoming $97,9 \%$.
\end{abstract}

Key words : gross motor skill, song and movement, 5-6 year old students

\section{PENDAHULUAN}

Pendidikan merupakan modal dasar untuk menyiapkan diri menjadi orang yang berkualitas. Anak - anak adalah generasi penerus bangsa. Kesadaran akan arti penting generasi penerus yang berkualitas mengharuskan kita serius membekali anak dengan pendidikan yang baik agar dirinya menjadi manusia seutuhnya dan menjadi generasi yang lebih baik dari pendahulunya.
Untuk menjadikan peserta didik yang berkualitas, maka sejak usia dini diperlukan pendidikan yang mampu mengembangkan potensi setiap anak agar tercipta generasi yang berkualitas. Sesuai dengan pasal 28 Undang undang Sistem Pendidikan Nasional No. 20/2003 ayat 1 , yang termasuk anak usia dini adalah anak yang masuk rentang usia 0 - 6 tahun. Sementara itu, menurut kajian rumpun ilmu Pendidikan Anak Usia Dini dan penyelenggaraannya di beberapa Negara, Pendidikan Anak Usia 
Jurnal Warna : Jurnal Pendidikan Dan Pembelajaran Anak Usia dini. September 2017. Vol 02. No. 02

Dini dilaksanakan sejak usia $0-8$ tahun (Hasan, 2009:17).

Pasal 28 Undang - undang menyatakan bahwa pendidikan anak usia dini dapat diselenggarakan melalui jalur pendidikan formal (taman kanak kanak, raudatul athfal, atau bentuk lain yang sederajat), atau jalur pendidikan informal yang berbentuk pendidikan keluarga atau pendidikan yang diselenggarakan oleh lingkungannya (Musbikin,2010 : 35).

Taman kanak - kanak (TK) merupakan lembaga pendidikan formal sebelum memasuki Sekolah Dasar. Lembaga ini sangat strategis dan penting dalam penyediaan pendidikan sebagai anak berumur $4-6$ tahun disebut anak usia peka. Serta anak pada masa ini sering disebut masa keemasan (Golden Age) yang didalamnya terdapat masa masa peka yang hanya datang sekali.

Taman kanak - kanak sudah termasuk pendidikan formal dalam jajaran Pendidikan Dasar dan Menengah. Hanya saja, Taman Kanak kanak tetap dikategorikan sebagai prasekolah untuk anak usia dini, sehingga tidak ada mata pelajaran yang mengikat untuk siswa, kecuali bermain dan bermain (Hasan, 2009 : 355).

Pendidikan pada usia Taman Kanak - Kanak 4-6 tahun merupakan wahana pendidikan yang sangat fundamental dalam memberikan kerangka dasar bentuk dan perkembangan dari sikap fisik anak masing - masing keberhasilan penyelenggaraan pendidik pada lembaga pendidik anak usia dini Taman Kanak Kanak seperti kelompok bermain di taman kanak - kanak sangat tergantung pada syistem dan proses pendidikan yang dijalankan setiap Taman Kanak Kanak masing - masing.

Sebagaimana terdapat dalam Garis - Garis Besar Program Kegiatan Belajar Taman Kanak - Kanak (Depdikbud,1994) tujuan program kegiatan belajar anak Taman Kanak Kanak adalah untuk membantu meletakan dasar kearah perkembangan sikap, pengetahuan, keterampilan, dan daya cipta yang diperlukan oleh anak didik dalam menyesuaikan diri dengan lingkungannya dan untuk pertumbuhan serta perkembangan selanjutnya. Sedangkan ruang lingkup program kegiatan belajar yang meliputi : pembentukan perilaku melalui pembiasaan dalam pengembangan moral pancasila, agama, disiplin, perasaan/emosi, dan kemampuan bermasyarakat, serta pengembangan kemampuan berbahasa, daya pikir, daya cipta, keterampilan dan jasmani.

Mengembangkan kreatifitas anak, maka diperlukan metode - metode yang tepat dalam mengajar sehingga tercipta suasana yang efektif yang dapat 
Jurnal Warna : Jurnal Pendidikan Dan Pembelajaran Anak Usia dini. September 2017. Vol 02. No. 02

memotivasi dan meningkatkan rasa ingin tahu anak. Oleh karena itu guru dituntut untuk menjadi kreatif dan inovatif dalam mengembangkan metode - metode serta media yang ada. Dalam memilih dan menentukan suatu pendekatan dan metode yang akan digunakan dalam program kegiatan anak di Taman Kanak - Kanak, guru perlu mempunyai alasan yang kuat dan faktor - faktor yang mendukung pemilihan metode dan pendekatan tersebut, seperti karakteristik tujuan kegiatan dan karakteristik anak yang diajar. Karakteristik tujuan adalah pengembangan kognitif, pengembangan sikap dan perilaku. Selain itu karakteristik anak juga ikut menentukan pemilihan metode.

Anak usia dini adalah anak yang aktif yang selalu bergerak, mempunyai rasa ingin tahu dan imajinasi yang tinggi serta mengekspresikan perasaannya melalui perilaku yang berbeda - beda. Anak tidak bisa diam dalam waktu yang lama, oleh karena itu dalam setiap gerakan anak terlibat koordinasi otot kasar.

Pada anak usia Taman KanakKanak (TK) perkembangan kemampuan anak akan sangat terlihat, salah satunya adalah perkembangan motorik anak yang sedang berkembang pesat di usia dini. Proses tumbuh kembang kemampuan motorik anak berhubungan dengan proses tumbuh kembang kemampuan gerak anak. Perkembangan kemampuan motorik anak akan dapat terlihat secara jelas melalui berbagai gerakan yang dapat mereka lakukan. Untuk mengembangkan kemampuan motorik anak, guru dapat menggunakan metode - metode yang menjamin anak tidak mengalami cidera. Oleh karena itu, guru perlu menciptakan lingkungan yang aman dan menantang. (Gordon \& Brown, 1985)

Pengembangan fisik motorik merupakan salah satu pengembangan kemampuan di Taman Kanak - kanak. Bahan kegiatan pengembangan fisik motorik mencakup kegiatan yang mengarah pada kegiatan untuk melatih motorik kasar dan halus yang terdiri dari gerakan - gerakan jalan, lari, lompat, senam, keterampilan dengan bola, keterampilan menggunakan peralatan, menari, latihan ritmik dan gerak gabungan.

Pemilihan metode untuk mengembangkan keterampilan motorik anak, guru perlu menyesuaikannya dengan karakteristik anak Taman kanak - Kanak yang selalu bergerak, susah untuk diam, mempunyai rasa ingin tahu yang kuat, senang bereksperimen dan menguji, mampu mengekspresikan diri secara kreatif, mempunyai imajinasi dan senang berbicara (Sujiono, 2005: 14). 
Jurnal Warna : Jurnal Pendidikan Dan Pembelajaran Anak Usia dini. September 2017. Vol 02. No. 02

Motorik kasar anak berkaitan dengan aktifitas fisik/jasmani dengan menggunakan otot - otot besar, seperti otot lengan, otot tungkai, otot bahu, otot punggung dan otot perut yang dipengaruhi oleh kematangan fisik anak. Perkembangan motorik berbeda dari setiap individu, ada anak yang perkembangan motoriknya sangat baik, namun ada juga yang memiliki keterbatasan fisik.

Bagi anak bernyanyi sambil menari adalah hal yang menyenangkan. Seringkali anak melakukan gerakan gerakan spontan saat ia sedang bernyanyi mengikuti lirik lagu yang dinyanyikan. Menurut Sujiono, dkk. (2005 : 5.4) menyebutkan "bahwa pola gerakan merupakan pengertian umum dan motorik merupakan gerak yang lebih khusus". Seringkali gerak dibedakan antara gerak halus dan gerak kasar. Gerak halus adalah gerak yang memerlukan ketelitian dan kecerdasan, sedangkan gerak kasar adalah gerakan seluruh tubuh dan bagian - bagian tubuh yang besar, seperti kegiatan yang berpindah tempat. Mutiah (2010:168) "gerak merupakan sarana ekspresi dan mengalihkan ketakutan, kesedihan, kemarahan, kenikmatan, dan sebagainya". Sementara itu Seefeldt \& Wasik (2008 : 304) menjelaskan bahwa "gerak merupakan bagian dari keberadaan alamiah anak - anak usia tiga, empat, dan lima tahun".

Gerak yang erat hubungannya dengan music merupkan isyarat yang efspresif dan membebaskan diri dari ketegangan melalui gerakan - gerakan ritmis. Anak - anak biasanya bergerak ketika mendengar bunyi music atau lagu. Dalam kegiatan awal pembelajaran, biasanya guru melakukan kegiatan seperti bernyanyi sambil bertepuk tangan atau bergerak mengikuti lirik lagu. Menurut Winaputra (2007 : 5.7), mengembangkan keterampilan gerak tubuh anak diantarannya: a) Senang menari, acting; b) Pandai dan aktif dalam olahraga; c) Mudah berekpresi dengan tubuh; d) Mampu memainkan mimik; e) Cenderung menggunakan bahasa tubuh; f) Koordinasi dan fleksibilitas; g) Senang dan efektif berpikir sambil berjalan, berlari dan berolahraga; h) Pandai merakit sesuatu atau tidak bisa diam dalam waktu yang lama.

Berdasarkan latar belakang ini maka dijadikan suatu landasan pada penelitian tindakan kelas dengan judul Meningkatkan Kemampuan Motorik Kasar Anak Melalui Gerak dan Lagu Usia $5-6$ Tahun di TK PGRI Marangkayu. Hal ini dikarenakan kurangnya kegiatan dalam melakukan 
Jurnal Warna : Jurnal Pendidikan Dan Pembelajaran Anak Usia dini. September 2017. Vol 02. No. 02

motorik kasar anak di TK PGRI Marangkayu.

\section{METODOLOGI PENELITIAN}

\section{Desain Penelitian}

Penelitian yang dipakai oleh peneliti adalah penelitian tindakan kelas (PTK). Penelitian ini dilakukan di Taman Kanak - Kanak PGRI Marangkayu pada kelompok B (5 - 6 tahun).

Penelitian dilakukan pada tahun ajaran 2017/2018 yang akan dilaksanakan dalam 2 siklus 6 kali pertemuan, dimana satu siklus akan dilaksanakan dalam waktu 2 minggu yang setiap pertemuannya dilaksanakan seminggu 3 kali.

\section{Subjek Penelitian}

Penelitian tindakan kelas ini yang menjadi subjek penelitian adalah siswa kelompok B (5 - 6 tahun) di TK PGRI Marangkayu.

\section{Objek Penelitian}

Objek penelitian ini adalah meningkatkan kemampuan motorik kasar anak melalui gerak dan lagu pada kelompok B (5 - 6 tahun)di TK PGRI Marangkayu.

\section{Prosedur Penelitian}

Penelitian berupa PTK,
dilaksanakan sejak bulan Juli tahun ajaran 2017/2018 pada kelompok B (5 6 tahun) di Taman Kanak - Kanak PGRI
Marangkayu. Penelitian tindakan kelas yang akan dilaksanakan merupakan sebuah proses pembelajaran dalam meningkatkan kemampuan motorik kasar anak melalui gerak dan lagu.

Prosedur atau langkah - langkah penelitian yang dilakukan terbagi dalam bentuk siklus kegiatan yang mengacu pada model yang diadopsi dari Hopkins (1993 : 48), dimana setiap siklus terdiri atas empat kegiatan pokok adalah kegiatan : perencanaan tindakan, pelaksanaan, observasi dan refelksi. Empat kegiatan ini berlangsung secara simultan yang urutannya dapat mengalami modifikasi.

Dalam praktik PTK menurut Mulyasa (2009 : 182), "Desain Penelitian Tindakan Kelas mengikuti model Lewin yang ditafsirkan oleh Kemmis (Wiraatmadja)"
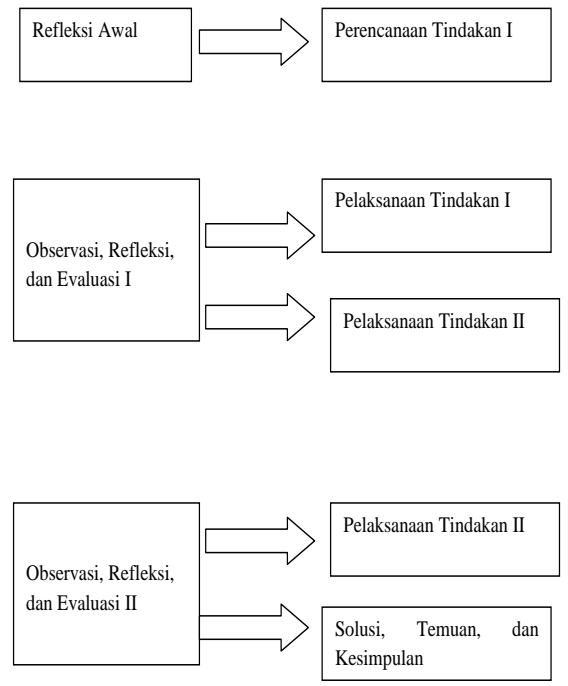

Gambar .1: Alur Penelitian Tindakan Kelas ( Mulyasa,2009 : 182 ) 
Jurnal Warna : Jurnal Pendidikan Dan Pembelajaran Anak Usia dini. September 2017. Vol 02. No. 02

Berdasarkan desain diatas, tahapan penelitian dijelaskan sebagai berikut :

\section{Refleksi Awal}

Pada tahap ini dilakukan identifikasi kesulitan siswa dalam meningkatkan motorik kasar. Dalam hal ini kegiatan yang akan dipakai untuk meningkatkan motorik kasar anak adalah melalui gerak dan lagu,

\section{Perencanaan Tindakan}

Penelitian akan dilaksanakan pada kelompok B (5 - 6 tahun) di Taman Kanak - kanak PGRI Marangkayu. Adapun langkah - langkah dalam perencanaan tindakan adalah berupa: 1) Pembuatan lembar insrument penelitian.

2) Membuat Rencana Pelaksanaan Pembelajaran Mingguan (RPPM) dan membuat Rencana Pelaksanaan Pembelajaran Harian (RPPH). 3) Mempersiapkan media pembelajaran. 4) Mempersiapkan materi pembelajaran.

Pelaksanaan tindakan

Pada tahap ini dilakuakn tindakan berupa pelaksanaan program pembelajaran yang bertujuan untuk meningkatkan motorik kasar pada anak dengan menggunakan kegiatan gerak dan lagu.

Observasi dan Refleksi

Tahap ini dilakukan untuk mengumpulkan data - data dan menganalisisnya untuk kemudian dapat diambil kesimpulan dari penelitian ini.
Sehingga mengetahui apakah terdapat titik kelemahan maupun kelebihan dan peneliti bisa melakuakan perbaikan pada siklus berikutnya.

\section{Tahapan Siklus}

\section{Refleksi Awal}

Pada tahap silkus pertama peneliti melakukan observasi pada kelompok B (5 - 6 tahun) di Taman Kanak - Kanak PGRI Marangkayu, dan menemukan suatu permasalahan dimana peneliti ingin meningkatkan motorik kasar pada anak. Dalam hal ini untuk meningkatkatkan motorik kasar pada anak dilakukan dengan menggunakan kegiatan gerak dan lagu.

Perencanaan Tindakan

Pada siklus pertama, peneliti mengawali kegiatan dengan melakukan langkah - langkah pembelajaran, seperti membuat Rencana Pelaksanaan Pembelajaran Mingguan (RPPM) dan Rencana Pelaksanaan Pembelajaran Harian (RPPH) dengan tema yang disesuaikan. Kemudian menyiapkan kegiatan yang berhubungan dengan gerak dan lagu, dan menyiapkan lembar observasi pembelajaran.

Pelaksanaan Tindakan

Pada siklus satu dilaksanakan sebanyak 3 kali pertemuan, dengan gerak dan lagu sebagai kegiatan dalam proses belajar mengajar. Sebelum memulai kegiatan belajar mengajar, anak akan berbaris terlebih dahulu. 
Jurnal Warna : Jurnal Pendidikan Dan Pembelajaran Anak Usia dini. September 2017. Vol 02. No. 02

Kegiatan gerak dan lagu akan dilakukan dalam kegiatan inti berlangsung. Dengan memperagakan gerakan yang akan diiringi dengan lagu, anak - anak akan mengikuti setiap gerakan yang akan diperagakan oleh guru didepan kelas.

\section{Observasi, refleksi dan evaluasi}

Tahap ini dilakukan untuk mengumpulkan data - data dengan menggunakan lembar observasi, menilai hasil pelaksanaan dalam proses belajar mengajar. Kegiatan mengevaluasi, analisis, penjelasan, penyimpulan dan identifikasi akan dilanjutkan pada siklus berikutnya, jika anak belum mencapai hasil yang maksimal.

\section{Tehnik Pengumpulan Data}

Observasi

Sudjana (2011 : 84) menjelaskan bahwa "observasi atau pengamatan sebagai alat penilaian banyak digunakan untuk mengukur tingkah laku individu atau proses kejadian suatu kegiatan yang dapat diamati”.

Dari penjelasan diatas peneliti menyimpulkan bahwa observasi adalah suatu tehnik pengumpulan data dengan cara mengamati subjek penelitian maupun objek penelitian serta keadaan sekitar tempat penelitian.

\section{Dokumentasi}

Dokumentasi merupakan "suatu tehnik pengumpulan data dengan menghimpun dan menganalisis dokumen - dokumen baik dokumen tertulis, gambar maupun elektronik". (Sukmadinata,2010 : 221)

Dalam pengumpulan data, peneliti hanya menggunakan foto sebagai studi dokumenter.

\section{Tehnik Analisis Data}

Penelitian kualitatif dilakukan sejak sebelum memasuki lapangan, selama dilapangan, dan setelah selesai dilapangan (Sugiyono, 2011 : 207). Data yang dikumpulkan setiap kegiatan observasi dari pelaksanaan siklus penelitian dianalisis secara deskriptif dengan menggunakan tehnik presentase untuk melihat kecenderungan yang terjadi dalam kegiatan pembelajaran (Kunandar, 2011:280).

Untuk mendapatkan data peningkatan kemampuan setiap anak, maka peneliti membuat patokan penilaian dalam mencapai keberhasilan. Biasanya keberhasilan siswa ditentukan kriteriannya, yakni berkisar antara $3-4$ skor dengan keterangan 3 skor yaitu Berkembang Sesuai Harapan (BSH) dan 4 skor yaitu Berkembang sangat Baik (BSB). Artinya, siswa dikatakan berhasil apabila ia menguasai atau dapat mencapai sekitar 3 - 4 skor dari tujuan ataunilai yang seharusnya dicapai. Adapun analisis data penelitian ini menggunakan rumus rata - rata sebagai berikut: 
Jurnal Warna : Jurnal Pendidikan Dan Pembelajaran Anak Usia dini. September 2017. Vol 02. No. 02

$$
\bar{X}=\frac{\sum \mathrm{x}}{\mathrm{N}}
$$

Keterangan :

$\bar{X}=$ Nilai rata - rata kelas

$\sum \mathrm{x}=$ Jumlah nilai hasil belajar seluruh siswa

$\mathrm{N}$ = Jumlah siswa

Rumus yang digunakan dalam penilaian presentase ketuntasan klasikal belajar setiap anak yaitu:

$$
K=\frac{\sum \text { Siswayangtuntas }}{\text { Jumlahseluruhsiswa }} \times 100 \%
$$

Keterangan :

$\mathrm{K}=$ Ketuntasan hasil belajar

(Kemmis,2007)

\section{Indikator Penilaian}

1. Anak mampu melakukan kelenturan gerak tubuh

2. Anak mampu melakukan gerakan keseimbangan badan

3. Anak mampu bergerak dengan lincah

4. Anak mampu melakukan gerakan tubuh sesuai gerak dan lagu

\section{Indikator Keberhasilan}

Penilaian ini dikatakan berhasil apabila jumlah anak telah mencapai $80 \%$ dengan katagori Berkembang Sangat Baik (BSB), Berkembang Sesuai Harapan (BSH), Mulai Berkembang (MB), Belum Berkembang (BB).

Keterangan:

BSB $($ Berkembang Sangat Baik $)=$ Skor 4

BSH $($ Berkembang Sesuai Harapan $)=$ Skor 3

MB (Mulai Berkembang) $=$ Skor 2
BB $($ Belum Berkembang $)=$ Skor 1

Presentase kemampuan motorik kasar dapat diketahui dengan menghitung rata - rata dari jumlah persentase kategori dapat, belum dapat, dan tidak dapat.

Tabel 1. ketuntasan Hasil Belajar Siswa

\begin{tabular}{|l|l|l|}
\hline No & Kriteria Nilai & Nilai \\
\hline 1 & Sangat rendah & $0-45 \%$ \\
\hline 2 & Rendah & $46-64 \%$ \\
\hline 3 & Sedang & $65-75 \%$ \\
\hline 4 & Tinggi & $76-85 \%$ \\
\hline 5 & Sangat tinggi & $86-100 \%$ \\
\hline \multicolumn{3}{|c|}{ (Kemmis, 2007) }
\end{tabular}

\section{TEMUAN DAN PEMBAHASAN}

\section{Hasil Temuan}

\section{Siklus I}

Berdasarkan data diatas dapat diketahui pada siklus I penelitian yang dilakukan pada hari Jumat, 28 Juli 2017, semua aspek penilaian belum memenuhi target penilaian, walaupun dapat dilihat setiap aspeknya terjadi peningkatan di banding pertemuan ke-2. Pada aspek kelenturan gerak tubuh mencapai 5\% berkembang sangat baik (BSB), 75\% berkembang sesuai harapan (BSH), 15\% mulai berkembang (MB), dan 5\% belum berkembang (BB), aspek keseimbangan gerak tubuh mencapai $15 \%$ berkembang sangat baik (BSB), 60\% berkembang sesuai harapan (BSH), 25\% mulai berkembang (MB), aspek kelincahan gerak tubuh mencapai $15 \%$ berkembang sangat baik (BSB), 85\% berkembang sesuai harapan $(\mathrm{BSH})$, dan kesesuaian antara gerak dan lagu mencapai $25 \%$ 
Jurnal Warna : Jurnal Pendidikan Dan Pembelajaran Anak Usia dini. September 2017. Vol 02. No. 02

berkembang sangat baik, $60 \%$ berkembang sesuai harapan (BSH), dan $15 \%$ mulai berkembang (MB). Hasil rekapitulasi keberhasilan anak dapat dilihat pada tabel sebagai berikut :

Tabel 2. Nilai Rata - rata Pencapaian Hasil Rekapitulasi Aspek penilaian Anak Siklus I

\begin{tabular}{|c|c|c|c|c|c|}
\hline No & Aspek Penilaian & P I & P II & P III & $\begin{array}{c}\text { Rata } \\
- \text { rata }\end{array}$ \\
\hline 1 & $\begin{array}{c}\text { Kelenturan } \\
\text { gerak tubuh }\end{array}$ & $\begin{array}{c}20 \\
\%\end{array}$ & $40 \%$ & $80 \%$ & $\begin{array}{c}46,6 \\
\%\end{array}$ \\
\hline 2 & $\begin{array}{c}\text { Keseimbangan } \\
\text { gerak tubuh }\end{array}$ & $\begin{array}{c}45 \\
\%\end{array}$ & $60 \%$ & $75 \%$ & $60 \%$ \\
\hline 3 & $\begin{array}{c}\text { Kelincahan } \\
\text { gerak tubuh }\end{array}$ & $\begin{array}{c}30 \\
\%\end{array}$ & $30 \%$ & $\begin{array}{c}100 \\
\%\end{array}$ & $\begin{array}{c}53,3 \\
\%\end{array}$ \\
\hline 4 & $\begin{array}{c}\text { Kesesuaian } \\
\text { antara gerak } \\
\text { dan lagu }\end{array}$ & $\begin{array}{c}40 \\
\%\end{array}$ & $40 \%$ & $85 \%$ & $55 \%$ \\
\hline \multirow{2}{*}{ Jumlah } & $\begin{array}{c}33 \\
75\end{array}$ & $\begin{array}{c}42,5 \\
\%\end{array}$ & $85 \%$ & $\begin{array}{c}53,7 \\
\%\end{array}$ \\
\hline
\end{tabular}

Hasil tabel rekapitulasi aspek penilaian motorik kasar anak pada siklus I pertemuan I,II,dan III mengalami peningkatan walaupun belum mencapai target keberhasilan dengan hasil presentase $53,7 \%$ dengan kriteria rendah sehingga masih perlu perbaikan dalam meningkatkan kemampuan motorik kasar anak.

\section{Siklus II}

Berdasarkan data diatas dapat diketahui pada siklus II pertemuan III penelitian yang dilakukan pada hari Jumat, 4 Agustus 2017, terjadi peningkatan pada kemampuan motorik kasar anak usia 5 - 6 tahun kelompok B TK PGRI Marangkayu. Adapun hasil rekapitulasi keberhasilanmeningkatkan motorik kasar anak dapat dilihat pada tabel berikut :
Tabel 3. .Nilai Rata - rata Pencapaian Hasil Rekapitulasi Aspek penilaian Anak Siklus II

\begin{tabular}{|c|c|c|c|c|c|}
\hline No & Aspek Penilaian & P I & PII & $\begin{array}{c}\mathrm{P} \\
\text { III }\end{array}$ & $\begin{array}{l}\text { Rata } \\
\text { - rata }\end{array}$ \\
\hline 1 & $\begin{array}{l}\text { Kelenturan } \\
\text { gerak tubuh }\end{array}$ & $\begin{array}{l}95 \\
\%\end{array}$ & $\begin{array}{l}95 \\
\%\end{array}$ & $\begin{array}{l}95 \\
\%\end{array}$ & $95 \%$ \\
\hline 2 & $\begin{array}{l}\text { Keseimbangan } \\
\text { gerak tubuh }\end{array}$ & $\begin{array}{c}10 \\
0 \\
\%\end{array}$ & $\begin{array}{c}10 \\
0 \\
\%\end{array}$ & $\begin{array}{c}10 \\
0 \\
\%\end{array}$ & $\begin{array}{c}100 \\
\%\end{array}$ \\
\hline 3 & $\begin{array}{l}\text { Kelincahan } \\
\text { gerak tubuh }\end{array}$ & $\begin{array}{c}10 \\
0 \\
\%\end{array}$ & $\begin{array}{c}10 \\
0 \\
\%\end{array}$ & $\begin{array}{c}10 \\
0 \\
\%\end{array}$ & $\begin{array}{c}100 \\
\%\end{array}$ \\
\hline 4 & $\begin{array}{c}\text { Kesesuaian } \\
\text { antara gerak dan } \\
\text { lagu } \\
\end{array}$ & $\begin{array}{l}95 \\
\%\end{array}$ & $\begin{array}{l}95 \\
\%\end{array}$ & $\begin{array}{c}10 \\
0 \\
\% \\
\end{array}$ & $\begin{array}{c}96,6 \\
\%\end{array}$ \\
\hline & Jumlah & $\begin{array}{c}97, \\
5 \\
\%\end{array}$ & $\begin{array}{c}97, \\
5 \\
\%\end{array}$ & $\begin{array}{l}98, \\
75 \\
\%\end{array}$ & $\begin{array}{c}97,9 \\
\%\end{array}$ \\
\hline
\end{tabular}

Hasil rekapitulasi aspek penilaian pada siklus II pertemuan I, II, dan III, telah mengalami peningkatan yang sangat baik, dan anak - anak telah mampu melaksanakan kegiatan gerak dan lagu dengan sangat baik. Pada keseluruhan aspek berkembang sangat baik (BSB) yaitu aspek kelenturan, keseimbangan, kelincahan, dan kesesuaian antara gerak dan lagu dan telah mencapai $97,9 \%$ yang berarti semua aspek telah tuntas.

\section{Pembahasan}

Berdasarkan pengamatan pada siklus I dan siklus II kemampuan motorik kasar anak meningkat pada setiap aspeknya. Hal ini dapat terlihat dari hasil rekapitulasi pada siklus I dan siklus II pada tabel berikut : 
Jurnal Warna : Jurnal Pendidikan Dan Pembelajaran Anak Usia dini. September 2017. Vol 02. No. 02

Tabel 4. Hasil Perbandingan Siklus I dan Siklus II

\begin{tabular}{|c|lr|c|c|}
\hline No & \multicolumn{2}{|c|}{ Aspek Penilaian } & $\begin{array}{c}\text { Siklus } \\
\text { I }\end{array}$ & $\begin{array}{c}\text { Siklus } \\
\text { II }\end{array}$ \\
\hline 1 & $\begin{array}{l}\text { Kelenturan gerak } \\
\text { tubuh }\end{array}$ & $46,6 \%$ & $95 \%$ \\
\hline 2 & $\begin{array}{l}\text { Keseimbangan gerak } \\
\text { tubuh }\end{array}$ & $60 \%$ & $100 \%$ \\
\hline 3 & $\begin{array}{l}\text { Kelincahan gerak } \\
\text { tubuh }\end{array}$ & $53,3 \%$ & $100 \%$ \\
\hline 4 & $\begin{array}{l}\text { Kesesuaian antara } \\
\text { gerak dan lagu }\end{array}$ & $55 \%$ & $96,6 \%$ \\
\hline \multicolumn{3}{|c|}{ Jumlah } & $53,7 \%$ & $97,9 \%$ \\
\hline
\end{tabular}

Berdasarkan hasil penelitian diatas dalam meningkatkan kemampuan motorik kasar anak melalui gerak dan lagu pada gerakan senam Abita, Pinguin, dan Ceria sangat mempengaruhi keberhasilan anak dalam kegiatan ini, dan peneliti sangat berperan penting dalam memberikan arahan dan bimbingan anak lebih aktif dan bersemangat.

\section{PENUTUP}

\section{Kesimpulan}

Berdasarkan hasil penelitian tindakan kelas yang telah dilakukan peneliti di TK PGRI Marangkayu melalui siklus I dan siklus II, analisis hasil dan pembahasan dapat disimpulkan bahwa Kemampuan Motorik Kasar Anak Melalui Gerak dan Lagu secara keseluruhan telah mengalami peningkatan yang sangat baik disetiap aspek penilaiannya. Adapun yang menjadi aspek dalam penelitian kemampuan motorik kasar ini adalah aspek kelenturan gerak tubuh, keseimbangan gerak tubuh, kelincahan gerak tubuh, dan kesesuaian antara gerak dan lagu.

Kegiatan gerak dan lagu disesuaikan dengan Rencana Kegiatan Harian (RPPH) dan Rencana Kegiatan Mingguan (RPPM) yang disesuaikan dengan tema, yakni Diri Sendiri subtema Tubuhku pada siklus I dan Diri Sendiri subtema Kesukaanku pada siklus II.

Dalam penerapannya, guru memberikan contoh yang mudah diikuti oleh anak yang disesuaikan dengan tingkat perkembangan anak.Adapun peningkatan disetiap aspeknya dapat dilihat pada lembar observasi setiap siklus dan hasil rekapitulasi aspek penilaiannya. Secara keseluruhan semua aspek meningkat dengan sangat baik.

\section{Saran}

Berdasarkan hasil penelitian, maka peneliti dapat memberikan beberapa saran sebagai berikut :

1. Bagi Sekolah : Meningkatkan sarana dan prasarana sekolah sehingga menunjang pembelajaran serta dapat meningkatkan kerjasama dengan rekan-rekan guru, orang tua dan masyarakat lingkungan sekolah/ belaja rmengajar di sekolah.

2. Bagi Guru : Meningkatkan kemampuan guru dalam mengembangkan program 
Jurnal Warna : Jurnal Pendidikan Dan Pembelajaran Anak Usia dini. September 2017. Vol 02. No. 02

pembelajaran dan meningkatkan

kemampuan guru dalam

menggunakan metode dan media

yang tepat dalam meningkatkan

perkembangan anak.

3. Bagi Orang tua : Membantu dalam proses belajar mengajar latihan gerak dan lagu yang sesuai dengan tingkat perkembangan anak.

\section{DAFTAR PUSTAKA}

Armstrong, Thomas. 2005. Setiap Anak Cerdas. Jakarta: Gramedia Pustaka Umum

Andrianti, dan Aiz Citragazza. 2013.Senam Abita.

Agus Candra Winata, Benamin.2011.Senam Pinguin.

Desmita. 2005. Psikologi Perkembangan. Bandung: Rosda

Hasan, Maimunah.2009. Pendidikan Anak Usia Dini. Jogjakarta: Diva Press

Hurlock, Elizabeth B. 1978. Perkembangan Anak. Jakarta: Erlangga

I.G.A.K. Wardani.2007.Penelitian Tindakan Kelas.Jakarta: Universitas Terbuka KTSP SD/MI 2011

Kunandar. 2011. Langkah Mudah Penelitian Tindakan Kelas Sebagai Pengembangan Profesi Guru. Jakarta: Raja Grafindo Persada.

Masitoh,dkk. 2004. Strategi pembelajaran TK. Jakarta : Universitas Terbuka

Moeslichatoen. 2004. Metode Pengajaran di Taman Kanak-kanak. Jakarta: Rineka Cipta
Mulyasa, E. 2009. Praktik Penelitian Tindakan Kelas. Bandung: Remaja Rosdakarya

Musbikin, Imam. 2010. Buku Pintar PAUD. Jogjakarta: Laksana

Muslich, Masnur. 2012. KTSP (Kurikulum Tingkat Satuan Pendidikan) Dasar Pemahaman dan Pengembangan. Jakarta: Bumi Aksara

Mutiah, Diana. 2010. Psikologi Bermain Anak Usia Dini. Jakarta: Kencana

Papalia, Diane E. 2008. Human Development ( Psikologi Perkembangan). Jakarta: Kencana

Prasetya. 2002. Filsafat Pendidikan. Bandung: CV.Pustaka Setia

Santrock, John W. 2007. Perkembangan Anak. Jakarta: Erlangga

Seefeldt, Carol dan Barbara A. Wasik. 2008.Pendidikan Anak Usia Dini. Macanan Jaya Cemerlang

Soejanto, Agoes. 2005. Psikologi Perkembangan. Jakarta: 2005

Soetjiningsih, Christina Hari. 2012. Perkembangan Anak Sejak Pertumbuhan Sampai Dengan Kanak-kanak. Jakarta: Prenada Media Group

Sudjana, nana. 2011 . Penilaian Hasil Proses Belajar Mengajar. Bandung: PT Remaja Rosydakarya

Sugiyono. 2011. Metode Penelitian Pendidikan Pendekatan Kuantitatif, Kualitatif, dan $R \& D$. Bandung: Alfabeta

Sujiono, Yuliani Nuraini. 2013. Konsep Dasar Pendidikan Anak Usia Dini. Indeks - Jakarta

Sujiono, Bambang, dkk. 2005. Pengembangan Fisik. Jakarta: Universitas Terbuka 
Jurnal Warna : Jurnal Pendidikan Dan Pembelajaran Anak Usia dini. September 2017. Vol 02. No. 02

Sukmadinata, Nana Syaodih. 2010. Metode

Penelitian Pendidikan. Bandung:

Remaja Rosdakarya

Suwito, Bambang. 2014. Senam Ceria Anak Indonesia

Yamin, Martinis dan Jamilah Sabri Sanan.

2010. Panduan Pendidikan Anak

Usia Dini PAUD. Jakarta: GP Press 